J. Lake Sci. (湖泊科学), $2007, \mathbf{1 9}(4): 465-472$

http://www. jlakes.org. E-mail: jlakes@ niglas. ac.cn

(c) 2007 by Journal of Lake Sciences

\title{
人类活动对乌梁素海湿地环境演变的影响分析
}

\author{
于瑞宏 ${ }^{1}$, 刘廷筀 ${ }^{2}$, 许有鹏 ${ }^{1}$, 李畅游 ${ }^{2}$ \\ ( 1 : 南京大学地理与海洋科学学院,南京 210093) \\ $(2$ : 内蒙古农业大学水利与土木建筑工程学院, 呼和浩特 010018$)$
}

摘 要: 乌梁素海是我国半荒漠地区具有很高生态价值和社会效益的大型多功能湖泊湿地 ${ }^{[1]}$, 是黄河流域最大的淡水湖 泊, 也是内蒙古河套灌区唯一的承泄途径. 乌梁素海的补给水源主要包括含高 $\mathrm{N}, \mathrm{P}$ 的农田退水, 工业废水以及生活污水, 这些退水及废污水的排人使得湿地环境发生着重大的变化. 本文在收集 1986-2004 年 19 年间 Landsat TM/ETM 遥感影 像数据的基础上,结合乌梁素海历史资料, 分析了 80 年代以来人类活动对湿地环境的影响, 这种影响主要体现在人工芦 苇面积不断扩大, 富营养化程度逐年增高, 水生资源迅速减少等方面, 尽管 2003 年以来"引黄入海"工程的实施某种程度 上缓解了湿地环境恶化的进程, 但湿地环境仍然面临严重的威胁.

关键词: 乌梁素海; 湿地环境; 人类活动; 富营养化

\section{The impacts of human activities on the Wuliangsuhai wetland environment}

YU Ruihong ${ }^{1}$, LIU Tingxi ${ }^{2}$, XU Youpeng ${ }^{1} \&$ LI Changyou ${ }^{2}$

(1: The School of Geographic and Oceanographic Sciences, Nanjing University, Nanjing 210093, P. R. China)

(2: College of Hydraulic and Civil Architecture Engineering, Inner Mongolia Agricultural University, Huhhot 010018 , P. R. China)

\begin{abstract}
Wuliangsuhai is the large-scaled multi-function lake-wetland with high ecological and social value in the semi-desert area of China ${ }^{[1]}$, the biggest freshwater lake in the Yellow River basin, and also the unique carrying and drainage way to the Hetao irrigation area. The major recharge sources of Wuliangsuhai wetland are irrigation return with high-density nitrogen and phosphorus, industrial wastewater and sewage. On the basis of Landsat TM or ETM data of 19 years from 1986 to 2004 , integrating with historical materials, the impacts of human activities on the wetland water environment were analyzed. These impacts mainly include the increase of artificial reeds area and dense water weed area, the deterioration of water environment, the rising of lake eutrophication, and the reduction of aquatic resources. Though the applications of the project diverting water from Yellow River to Wuliangsuhai wetland slow down the process of the deterioration of the wetland environment, the Wuliangsuhai wetland still confronts with serious threat.
\end{abstract}

Keywords : Wuliangsuhai; wetland environment; human activities; eutrophication

随着人类改造自然能力的不断增强, 人类活动对湿地环境特性的影响愈加明显, 其中, 人口的增长、工 农业生产的发展及城市化进程的加快都显著改变着天然状态下的环境进程. 人类活动是干旱、半干旱地区 湖泊水位变化的重要原因之一 ${ }^{[2]}$, 而湖泊水位的变化又与湖泊营养程度的改变及水生植物的生长存在着 密切关系 ${ }^{[3]}$, 因此, 人类可以通过调节水位间接对湖泊环境产生影响; 另一方面,水利工程的建设, 大规模 的土地开发利用,农田灌溉的实施, 地方工业的发展等人类活动也可通过污染物的排放和转移使得湖泊环 境发生显著变化.

湖泊富营养化影响着世界范围内的水生生态系统 ${ }^{[4-6]}$,其中由于农田退水及生产、生活废水的排人导

* 国家自然科学基金 $(40571025,50269001,50169002)$ 资助. 2006-10-11 收稿;2007-01-23 收修改稿. 于瑞宏, 女, 1978 年生,博士研究生; E-mail : yrh0108@163.com. 
致的湖泊氮、磷含量不断富集已经引起广泛关注 ${ }^{[7-9]}$. 磷的含量可用做富营养化风险性的检测标准, 湖泊 面积可以用来评估湖泊保护的重要性,而水深则被用于营养物减少的潜在反映 ${ }^{[2]}$, 可见在湖泊环境演变研 究中, 湖泊面积及水深的变化是其中的两个重要研究内容. 一方面, 湖泊面积的变化对水质及水生生物资 源的再生循环过程产生了较大影响; 另一方面,水环境的改变及大型水生植物的生长又对湖泊水深 ${ }^{[10-12] 、}$ 面积、湖底坡度及其方位的改变产生响应, 且在相同年份的不同时期这种响应有着显著差异 ${ }^{[13]}$. 因此,通 过分析湖泊面积及水深发生变化的原因,便可以了解湖泊环境发生改变的原因, 从而明确人类活动在湖泊 环境改变中所起的作用. 湖泊环境演变是在气候条件及人类活动的双重影响下发生发展的,在气候变化的 大背景下, 人类活动的影响不容忽视.

本文以内蒙古自治区的淡水湖泊乌梁素海为例,着重分析人类活动影响下湖泊环境的演变过程, 目的 是找出湖泊污染和富营养化的主导因素, 以便更合理地寻求解决湖泊富营养化的理论依据和技术措施, 为 湖泊水污染控制和富营养化治理提供技术支持, 保护水体的生物多样性, 实现湖泊生物资源、旅游资源、水 资源的合理开发和永续利用.

\section{1 研究区概况}

乌梁素海位于内蒙古自治区巴彦淖尔市乌拉特前旗境内 (图 1a), 介于北纬 $40^{\circ} 36^{\prime}-41^{\circ} 03^{\prime}$, 东经 $108^{\circ}$ $43^{\prime}-108^{\circ} 57^{\prime}$ 之间. 据乌拉特前旗气象站 $1956-2004$ 年气象监测资料统计, 多年平均降水量为 $219.5 \mathrm{~mm}$, 降水主要集中在 $7-9$ 月, 占全年总降水量的 $67.9 \%$; 多年平均水面蒸发量为 $1396.3 \mathrm{~mm}$ ( E601 蒸发器实测 值),5-7 月蒸发量占全年总蒸发量的 $47.4 \%$; 多年年平均气温为 $6.6^{\circ} \mathrm{C}, 7$ 月份气温最高, 多年平均值为 $24.6{ }^{\circ} \mathrm{C}, 1$ 月份气温最低,多年平均值为 $-10.2^{\circ} \mathrm{C}$; 每年 11 月至翌年 2 月, 月平均气温低于 $0{ }^{\circ} \mathrm{C}$, 导致水体表 层冻结,冻结厚度约 $80 \mathrm{~cm} .2004$ 年乌梁素海总面积为 $376.298 \mathrm{~km}^{2}$ (含人工芦苇面积), 湖泊水位控制高程 $1018.5 \mathrm{~m}$, 水深约 $0.5-3 \mathrm{~m}$, 其中水深在 $0.8-1.0 \mathrm{~m}$ 的水域占 $80 \%$, 蓄水量约 $(2.5-3) \times 10^{8} \mathrm{~m}^{3[14]}$.

此外,乌梁素海是黄河流域大型灌区 - 河套灌区灌排工程的重要组成部分, 它由人工修筑的海坝分为 海坝以南和海坝以北两个区 (图 $1 \mathrm{~b}$ ), 海坝以南湖区的补给水源主要为河套灌区的农田退水, 工业废水和生 活污水,而海坝以北直接从海坝以南湖区引水获得水源补给, 维持其水生生态环境.

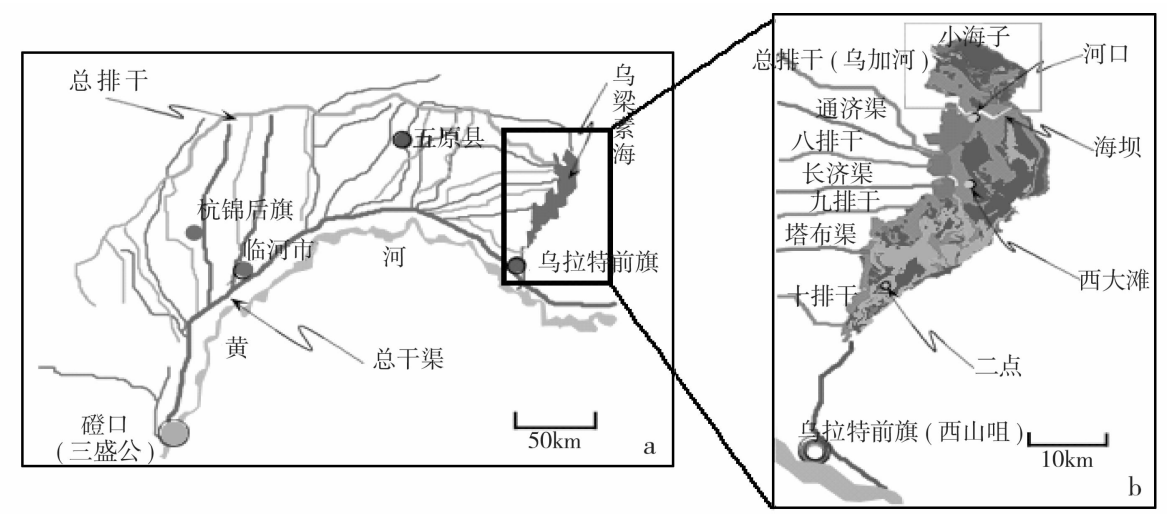

图 1 乌梁素海地理位置 (a: 河套灌区区域图; $\mathrm{b}$ : 乌梁素海周边放大图)

Fig. 1 Position of Wuliangsuhai

\section{2 数据来源}

(1) 遥感影像数据. 从中国遥感地面站购买了乌梁素海 1986-2004 年 19 年间的 Landsat TM 或 ETM 遥感影像数据, 其中; $1986-1999$ 年及 $2003-2004$ 年为 Landsat TM 数据, 2000-2002 年为 Landsat ETM 数 据, 各年数据均选自芦苇、水草生长旺盛的 8 月份, 如 8 月份卫片有云雾遮挡,则选取 9 月份的影像数据.

(2) 地方监测数据. 乌梁素海 $1986-2004$ 年 19 年间的水文气象及水质监测数据由巴彦淖尔市乌拉特 
前旗气象站、巴彦淖尔市河套灌溉管理总局及乌拉特前旗环境监测站提供. 水文气象数据包括降水、蒸发、 人湖水量及出湖水量等;水质监测数据包括总磷, 总氮, 溶解氧, 矿化度, 透明度,耗氧量等.

(3) 实测资料. 在获取乌梁素海遥感影像数据及地方监测数据的基础上,于 $2002-2004$ 年 3 年间每月 中旬对乌梁素海的水质进行定期监测, 其中实地观测项目包括水深 (冬季为冰厚), 底泥厚度, 水色, 植物生 长状况, 水草类型等; 室内实验项目包括 $\mathrm{EC}$ (电导率), $\mathrm{pH}$, 水温, 电导率, 浊度, 总磷, 总氮, 溶解氧, $\mathrm{COD}$, BOD 等.

\section{3 人类活动对乌梁素海湿地环境的影响}

乌梁素海处于干旱寒冷的气候条件下, 自然地理状况决定了乌梁素海独特的环境特征, 而人类活动的 干预则加速或延缓着湖泊的发展, 并影响着湖泊环境的演化过程, 其中, 水利工程的修建, 围湖造田,农田灌 溉的实施,地方工业的发展及人工芦苇的种植对乌梁素海湿地环境的影响尤为突出.

\section{1 水利工程的建设及乌梁素海面积的演化}

乌梁素海的成因与黄河的改道及河套平原农业灌溉的发展密切相关 ${ }^{[15]}$. 黄河的改道为乌梁素海的形 成创造了条件,而河套平原水利工程及各大灌渠的建设则为乌梁素海的发展扩大提供了通道.

20 世纪 60 年代,乌梁素海水域面积约为 $400 \mathrm{~km}^{2}$; 70 年代初期, 由于围湖造田、持续干旱和黄河过境水 量减少以及灌区排水系统不健全等原因,使湖泊面积显著减小; $1969-1976$ 年间,湖水面积仅有 $247 \mathrm{~km}^{2}$; 1977 年 7 月因乌梁素海流域普降暴雨, 导致湖泊水位持续 $20 \mathrm{~d}$ 猛涨, 使西北岸堤决口, 湖面扩展了 $46 \mathrm{~km}^{2}$, 增至 $293 \mathrm{~km}^{2}$ ( 以上面积均为海坝以南面积).

自 1986 年以来, Landsat TM/ETM 数据的获取,提高了乌梁素海环境要素监测的准确性和时效性. 根据 2002 年实地踏勘资料, 并参照 1986 年以来乌梁素海的历史资料及历年同期卫星影像信息, 从 $1986-2004$ 年间选择出 8 个典型年, 通过遥感影像的合成解译,将乌梁素海划分为明水区、芦苇区、密集水草区、沼泽 区、浅水区及人工芦苇区 6 部分,通过不同类型区面积的解译与统计,将全湖及海坝以南各类型区面积的变 化曲线绘制于图 2. 由图 2 可以看出: 就全湖而言 (包括海坝以南及海坝以北面积),1986-2004 年间全湖 总面积总体上呈递增的趋势, 由 1986 年的 $320.713 \mathrm{~km}^{2}$ 增加到 2004 年的 $376.298 \mathrm{~km}^{2}$; 对于海坝以南而言, 1986 年海坝以南总面积为 $261.12 \mathrm{~km}^{2}, 2004$ 年增加到 $310.106 \mathrm{~km}^{2}$, 扣除人工芦苇后的面积为 $281.266 \mathrm{~km}^{2}$, 海坝以南总面积同样呈增加趋势.
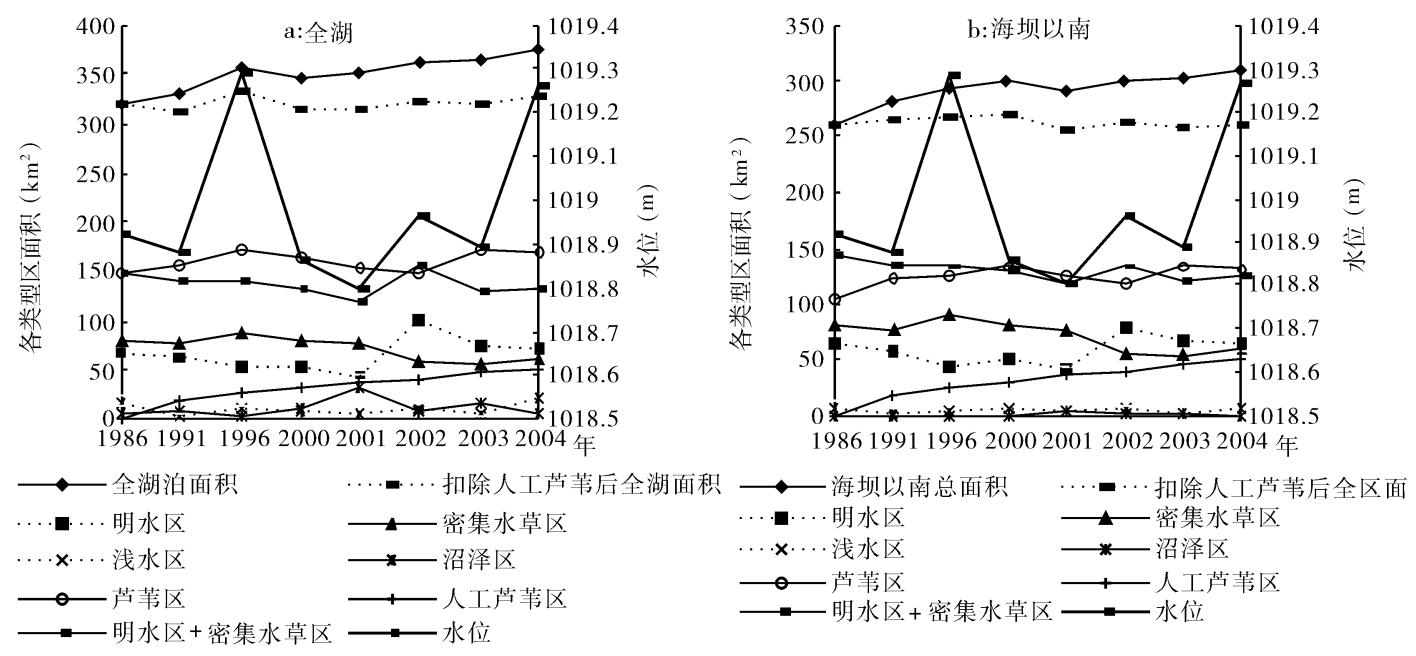

图 2 乌梁素海全湖面积及海坝以南面积的变化

Fig. 2 Variation of area of the whole lake and the southern Haiba of Wuliangsuhai wetland 
为进一步说明乌梁素海面积变化与气候条件及来水条件的关系,绘制了 8 个典型年的人湖水量、出湖 水量、净人湖水量 (人湖水量与出湖水量之差)、E601 水面蒸发量、降水量、净湖面蒸散发量 (水面蒸发量减 去降水量后,再乘以湖面面积）、卫片获取日期前的汛期降水量的变化曲线 (图 3). 由图 3 可以看出, 1986 -2004 年净人湖水量和净湖面蒸散发量总体上呈增加的趋势,且前者略大于后者;2002 年以前卫片获取日 期前的汛期降水量与湖泊水位的变化一致,然而,2003 年尽管汛期降水量较大,但净人湖水量出现 1991 年 以后的最小值 $3.501 \times 10^{8} \mathrm{~m}^{3}$ (加人引黄水量 $1400 \times 10^{4} \mathrm{~m}^{3}$ ), 水位偏低;2004 年尽管汛期降水量小于 2003 年数值, 但为了改善湖泊水环境状况, 春夏季人工引黄河水 $5100 \times 10^{4} \mathrm{~m}^{3}$, 使 2004 年净人湖水量出现 1986 年以来的最大值 $5.145 \times 10^{8} \mathrm{~m}^{3}$, 水位偏高. 结合图 $2 \mathrm{~b}$ 海坝以南面积的变化曲线可以得出, 汛期因降雨形成 的地表洪水及地下径流流人量 (因无观测数据, 以卫片获取日期前的汛期降水量表示)、净人湖水量是造成 夏季湖泊水位波动,湖泊总面积变化及各类型区面积相互转化的重要原因.

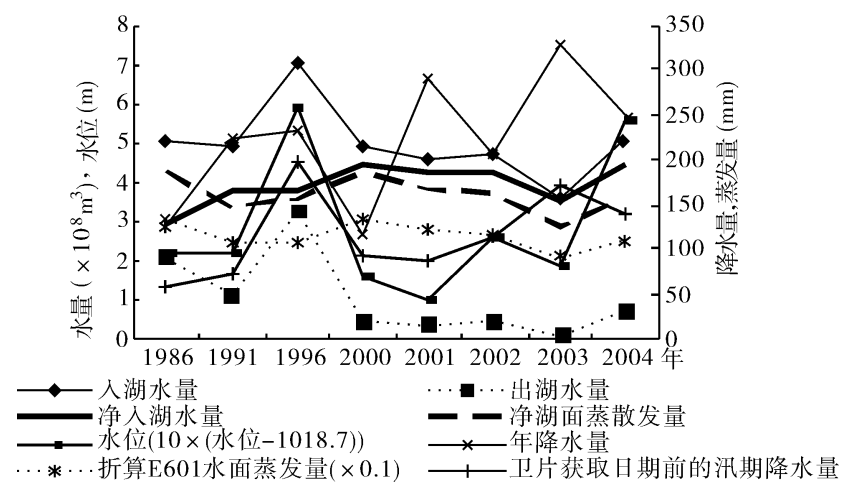

图 3 乌梁素海水文气象因子的历年变化

Fig. 3 Yearly variation of climatic factors

in Wuliangsuhai wetland

乌梁素海内部各类型区中, 密集水草 区, 沼泽区与芦苇区面积变化与湖泊营养 物含量的关系较大, 通过相关分析, 密集水 草区、沼泽区、芦苇区总面积与总氮、透明 度、耗氧量、溶解氧、矿化度、总磷的相关系 数分别为 $0.2564 、 0.2088 、 0.1499 、 0.0985$ 、 $0.0985 、 0.0292$, 相关系数尽管不大, 但总体 上也反映出总氮、透明度、耗氧量是促进湖 泊水生植物生长的重要因子,也是加速湖 泊沼泽化进程的重要因子. 就 2004 年而 言,乌梁素海在扣除人工芦苇的前提下, 海 坝以南面积为 $281.266 \mathrm{~km}^{2}$, 较 1977 年的 $293 \mathrm{~km}^{2}$ 减少了 $11.734 \mathrm{~km}^{2}$, 而 2004 年、 1977 年湖泊水位分别为 $1019.261 \mathrm{~m}$ 与 1019. $258 \mathrm{~m}$, 水位基本相同, 这说明随着时间的推移, 相同水位条件下乌梁素海海坝以南总面积正在缩小, 而同时由于河套灌区化肥施用量的逐年增多, 携带高浓度氮营养盐的农田退水的不断排人和湖泊水循环速 度的减慢, 导致湖泊氮累积量逐年增加, 已经大大超过了湖泊的氮临界负荷, 富营养化程度不断提高.

此外,由以上资料分析可知,乌梁素海水域总面积的变化主要受气候条件及来水条件的影响,但在特定 情况下, 如由于人工修建的水坝发生溃堤或决口 (1977 年), 湖泊环境与人类活动的相关性就会骤然增大. 因此,水坝、灌排工程的建设及其运行状况对于湖泊环境的变化影响重大,而这种影响的结果则具有两面 性. 一方面,灌排工程及水利工程的运行可能对湿地环境产生负面影响. 如 1996 年河套灌区实施节水改造 工程, 加上灌区排水系统的破坏, 导致人湖水量不断减少, 然而人们为了获取更大的芦苇产量和经济效益, 必须保证有较大的湖泊水面与水深, 因此减少湖泊的泄放水量, 导致湖泊水循环速度减慢, 营养盐富集, 芦 苇、水草生长旺盛, 湖底生物填平作用不断加剧, 湖泊环境恶化. 另一方面, 引水工程的开展也能使得湖泊 环境有所好转. 2003 年地方部门对进人乌梁素海的三条退水渠道长济渠、通济渠及塔布渠进行了深挖改 造, 使各渠的过水能力均达到 $20 \mathrm{~m}^{3} / \mathrm{s}$, 为 “引黄人海” 工程的实施创造了条件, 当年乌梁素海引黄河流凌水 $1300 \times 10^{4} \mathrm{~m}^{3}$, 夏季间隙水 $100 \times 10^{4} \mathrm{~m}^{3}, 2004$ 年乌梁素海又引黄河水 $5100 \times 10^{4} \mathrm{~m}^{3}$. 该工程的实施, 增加了 乌梁素海的人湖水量, 稀释了乌梁素海营养物质的浓度, 加快了乌梁素海的水体循环, 从而使其水环境状况 有所改观,湿地和湖泊功能在某种程度上得到恢复. 因此, 人类活动的干预可能对湖泊环境产生正面或负 面的影响, 只有适宜的水利工程建设才能保证乌梁素海湿地环境的持续发展.

\section{2 农田退水及工业废水的排入}

乌梁素海西岸自北至南有总排干 (乌加河)、通济渠、八排干、长济渠、九排干、塔布渠和十排干等主要 灌溉渠道和排水沟与湖体相连 (图 1b). $1984-2004$ 年间,灌排渠系多年平均人湖水量为 $5.692 \times 10^{8} \mathrm{~m}^{3}$; 湖水主要消耗于水面蒸发和水生植物蒸腾,多年平均年蒸发蒸腾总量为 $3.645 \times 10^{8} \mathrm{~m}^{3}$, 其次是退水,多年 
平均退水总量 (出湖水量) 为 $2.087 \times 10^{8} \mathrm{~m}^{3}$, 湖泊南端的泄水闸将湖水泄人总退水渠, 之后排人黄河. 每年 进人乌梁素海氮、磷的途径主要包括农田排水、地下水、山洪、灌渠退水、降水等,近年来平均每年人湖总氮 约 $1088.59 \mathrm{t}$, 总磷约 $65.75 \mathrm{t}$; 每年排出乌梁素海氮、磷的途径主要包括排人黄河的退水、收割芦苇及打捞水 草等, 平均每年出湖总氮约 $759.90 \mathrm{t}$, 总磷约 $37.80 \mathrm{t}$; 而每年滞留在湖中参与积累储备的总氮约为 328.70 $\mathrm{t}^{[16]}$. 据叶雪梅等关于中国主要湖泊营养氮沉降临界负荷的研究结果, 乌梁素海氮沉降临界负荷为 40.295 $\mathrm{t}^{[17]}$, 而目前乌梁素海水体中总氮储备量已达临界负荷的 8.16 倍, 总氮储备量的不断增加无疑将加速湖泊 的衰亡过程.

3.2 .1 农田退水 农业面源污染对乌梁素海的影响巨大, 每年农田退水都会携带大量的营养盐排人乌梁素 海,使其水体富营养化程度不断提高. 1980 年河套灌区化肥施用量仅 $6.6 \times 10^{4} \mathrm{t}, 1991$ 年增长到 $34.8 \times 10^{4}$ $\mathrm{t}, 1992$ 年由于开始施用浓缩化肥, 化肥施用量急剧减少到 $12 \times 10^{4} \mathrm{t}$, 但 1992 年以后化肥施用量又呈持续增 加趋势, 到 2004 年已迅速上升到 $55 \times 10^{4} \mathrm{t}$ (图 4), 而化肥利用率仅 $30 \%{ }^{[18]}$, 于是流失的化肥随农田退水进 人乌梁素海, 营养盐随即在湖中咜存, 成为水草和芦苇蒀延的动力, 而后水草及芦苇的残骸在湖底腐烂变 质,使湖水水质严重变坏, 同时加速了乌梁素海沼泽化的进程.

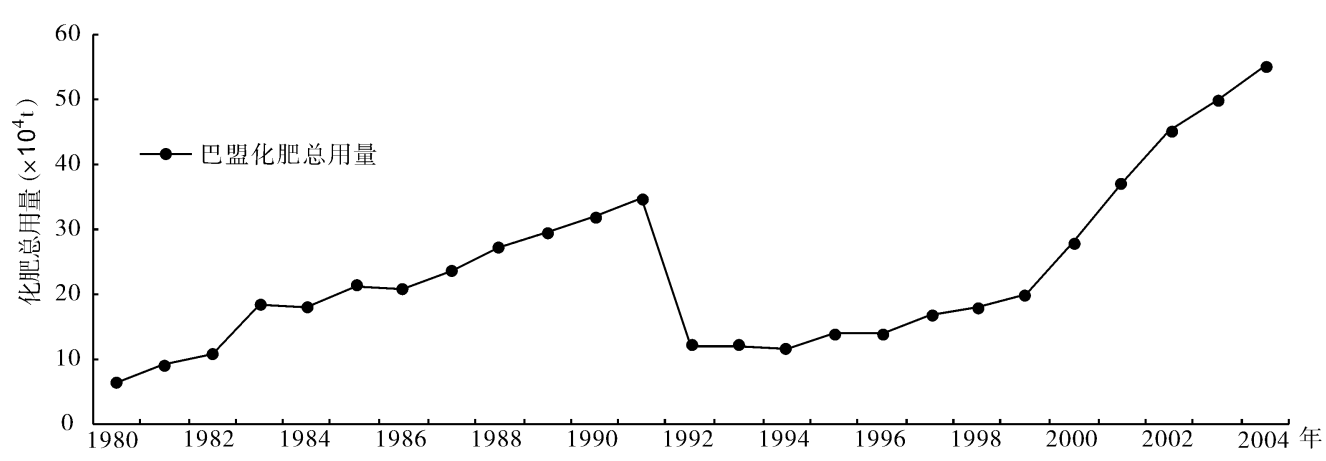

图 $41980-2004$ 年巴盟河套灌区化肥总用量变化

Fig. 4 Total quantities of Fertilizers used in Hetao irrigation area from 1980 to 2004

3.2 .2 工业废水及生活污水影响乌梁素海水质的工业污染源主要有: 杭锦后旗的飞亚调味品厂、河套酒 业集团、河套木业; 临河市的豪浆造纸厂5303 服装厂、金川啤酒厂;五原市的红昌化学工业有限公司、润泽 稀土有限公司、大名才造纸厂等. 三个地区工业污染源的排放量分别为: 杭锦后旗 $148 \times 10^{4} \mathrm{~m}^{3} / \mathrm{a}$ 、临河 493 $\times 10^{4} \mathrm{~m}^{3} / \mathrm{a}$ 、五原 $81 \times 10^{4} \mathrm{~m}^{3} / \mathrm{a}$, 因此,每年排人乌梁素海的工业污水量平均为 $722 \times 10^{4} \mathrm{~m}^{3}$. 另外,每年排人 乌梁素海的生活污水量约为 $720 \times 10^{4} \mathrm{~m}^{3}$.

通过对乌梁素海农田退水、工业污水及生活废水排放量数据的整理分析 (图 5 ) 可知: 人湖 TP 浓度在 2001 年达到最高值, 其后逐年降低, 说明乌梁素海上游工业及生活污水排放得到一定程度的控制, 然而出 湖与湖中 TP 浓度值变化不明显, 这是由于湖中的磷一部分被芦苇、水草等水生植物带走, 另一方面水中磷 浓度又与水流速度有关, 当水中磷浓度超过一定限值时, 则沉积湖底, 使湖泊底泥含磷量增大, 基于以上原 因, 使得 TP 浓度在湖中及出湖口变化不大, 趋于平稳. 由图 6 的 TN 浓度变化可以看出, 1998-2004 年间, 人湖 TN 浓度除 2001 年有所波动外, 其余各年总体上呈逐年递增趋势, 而湖中及出湖的 TN 浓度值总体上 也呈增加的趋势, 但 2004 年 TN 浓度较 2003 年略有降低,降低的原因可能在于 “引黄入海” 工程的实施, 稀 释了湖中氮磷等营养物质.

由以上分析不难看出, 目前乌梁素海水质状况仍然不容乐观. 尽管工业污染源得到部分控制, 加上农 闲时期黄河水的引人, 在某种程度上缓减了湖泊水质的进一步恶化, 但农业面源污染的营养物质仍然难以 控制. 因此, 为了有效控制湖体富营养化程度进一步加重,农业退水、工业废水及生活污水的排放标准及排 放方式等问题的解决迫在眉睫. 


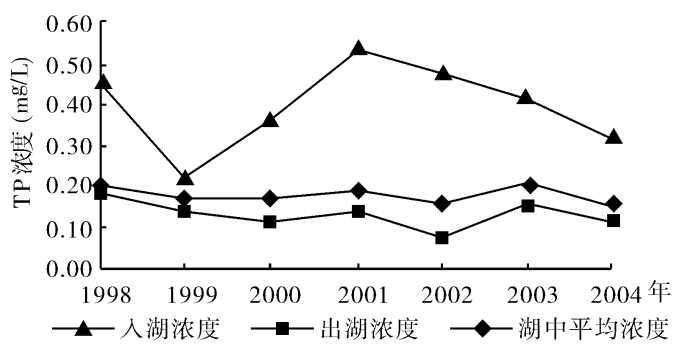

图 $51998-2004$ 总磷浓度变化

Fig. 5 Variation of total phosphorus from 1998 to 2004

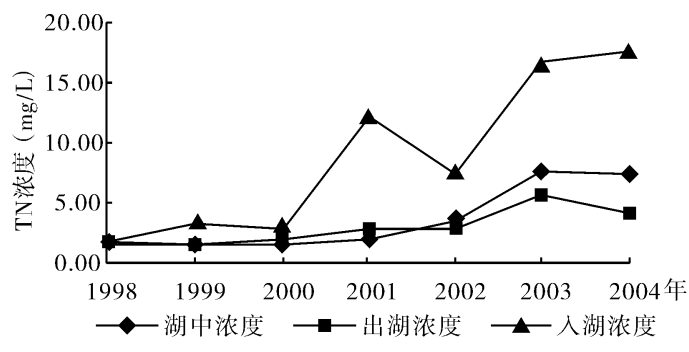

图 61998-2004 总氮浓度变化

Fig. 6 Variation of total nitrogen from 1998 to 2004

\section{3 芦苇区的扩展}

乌梁素海有大型水生植物共 6 科 6 属 11 种, 均属世界广布种, 其中以芦苇、龙须眼子菜 (Potarmogeton pectinatus L. )、穗花狐尾藻为优势种, 沉水植物、挺水植物、浮水植物遍布全湖,生长繁茂. 目前, 芦苇面积约 占乌梁素海湖面的 $1 / 2$, 主要分布在湖的中部、西岸和北部, 年产干苇 $12 \times 10^{4} \mathrm{t}$ (2000 年), 是重要的造纸原 料生产基地. 芦苇外围生长着少量香蒲, 面积不大. 芦苇区以外的明水区, 基本布满了沉水植物, 鲜草产量 可达 $12 \mathrm{~kg} / \mathrm{m}^{2}$.

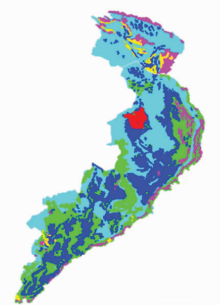

a 1986

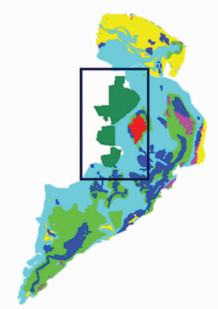

e 2001

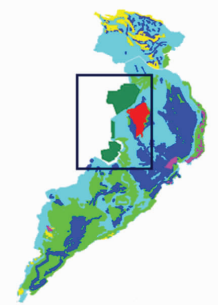

b 1991

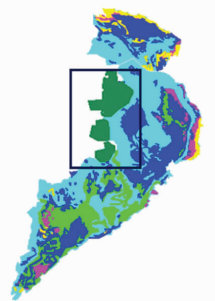

f 2002

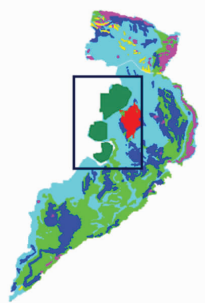

c 1996

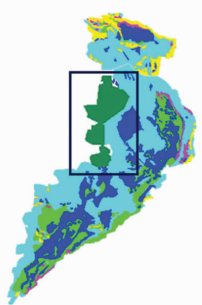

g 2003

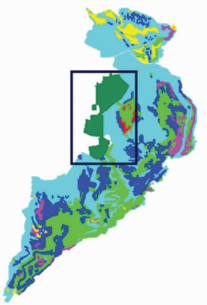

d 2000

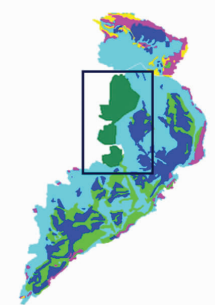

h 2004

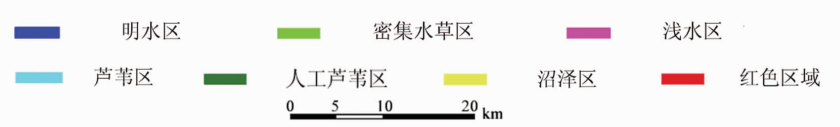

图 7 乌梁素海自然芦苇及人工芦苇分布情况

Fig. 7 Distribution of the natural reeds and artificial reeds in Wuliangsuhai

目前,乌梁素海生物填平作用过快, 每年湖底高程以 2-5 cm 的速度增加 ${ }^{[19]}$, 而芦苇的生长也明显受 到水深及底泥有机质积累的影响. 研究结果表明,水深是制约乌梁素海芦苇生物量的首要因素, 其不仅是 群落竞争和演替的重要因素, 同时也间接影响芦苇的生长状况和生物量; 而氮则是自然芦苇生长的限制 因子 ${ }^{[20]}$.

乌梁素海全湖自然芦苇区面积占绝对优势, 且基本呈逐年增加的趋势,而人工芦苇的种植则加速了芦 
苇区扩展的速度和范围,芦苇区在湖中的分布见图 7 (根据 8 个典型年卫片解译结果获得), 其面积变化见 图 2a 及图 2b. 由图 7 结合图 2 可知, 对于自然芦苇而言, 无论是全湖还是海坝以南, 其面积总体上呈增加 趋势; 就人工芦苇而言, 自 1988 年当地居民开始在海坝以南种植芦苇以来, 人工芦苇区面积呈持续增加态 势, 1991 年人工芦苇区面积为 $14.46 \mathrm{~km}^{2}$,而 2004 年其面积已扩展为 $27.693 \mathrm{~km}^{2}$.

芦苇是造纸厂的主要生产原料,自 1980 至 2000 年间,芦苇产量呈逐年增加趋势, 而芦苇收人也随之陡 增 (图 8). 1980 年芦苇产量仅 $2.6 \times 10^{4} \mathrm{t}$, 到 2000 年已上升到 $12 \times 10^{4} \mathrm{t}$, 而芦苇收人也由 1980 年的 197 万 元迅速增长为 2000 年的 1056 万元,芦苇产量与当地居民的经济收人息息相关. 尤其是 1988 年种植人工芦 苇以后, 导致 1989 年芦苇产量为 $1980-1996$ 年间的最大值, 而收人幅度也较前些年有所增加; 1992 年以 后,芦苇产量增加的速度明显较 80 年代增快,而居民收人也呈现同步增加的趋势. 由此可见,经济利益的 驱动是人工芦苇种植的根本原因, 然而在芦苇大面积种植的背后, 则是湖泊自然消亡过程的加速. 经测定, 乌梁素海大型水生植物总生产力高达 $360 \times 10^{4} \mathrm{t} / \mathrm{a}$, 全湖芦苇曼延, 由于芦苇及水草等植物残骸腐烂沉积, $1950-2000$ 年湖底累计沉积厚度已达 $360 \mathrm{~mm}^{[21]}$, 年平均沉积厚度约 $7.2 \mathrm{~mm}$, 致使乌梁素海已成为世界上 沼泽化速度最快的湖泊之一。

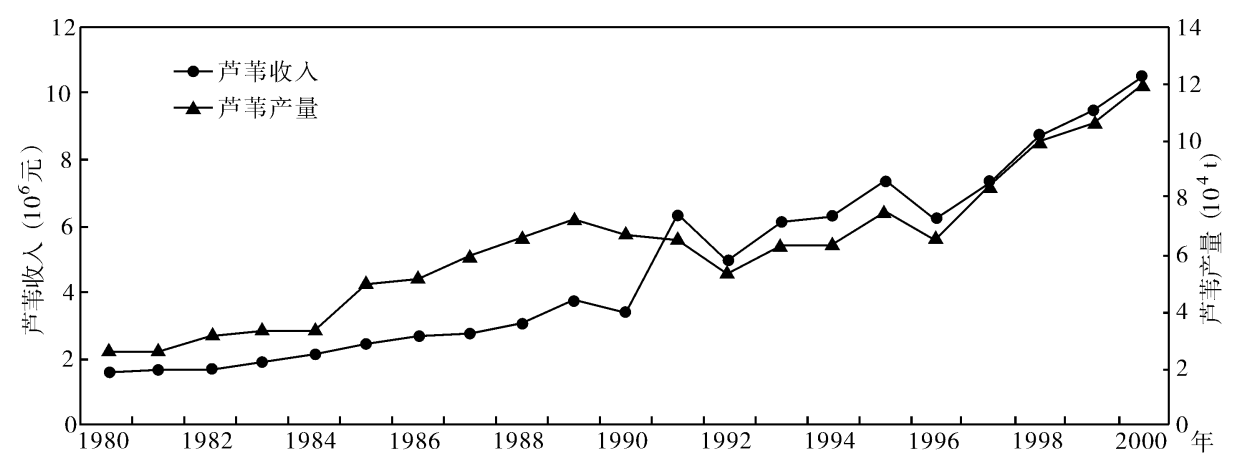

图 $81980-1999$ 年乌梁素海芦苇产量与芦苇收人变化

Fig. 8 Outputs and incomes of reeds from 1980 to 1999 in Wuliangsuhai wetland

\section{4 结论}

气候变化和人类活动是影响乌梁素海环境演变的两大主要因素, 在寒冷干旱气候条件的大背景下, 人 类活动对湖泊环境演变起着不可忽视的作用. 通过上述分析, 可以得出以下结论:

(1) 人类活动对乌梁素海湿地环境演变具有双重影响. 一方面,营养物的过量排人超过了湿地环境承 载力, 而导致湿地环境恶化; 另一方面, “引黄人海” 工程的实施, 加速了乌梁素海水量循环, 稀释了湖泊中 的富营养化物质,使湖泊水质有所改善.

(2)农田退水,工业污水及生活废水是乌梁素海的主要污染源, 其中氮、磷等营养物的不断排人,使得 水草及芦苇蔓延,继而其残骸在湖底腐烂变质, 使湖水水质变差, 加速了乌梁素海的沼泽化进程, 因此提高 农用化肥的利用率, 控制含高营养盐的农田退水的排放量, 实现污废水达标排放对改善乌梁素海水环境有 重大作用.

(3) 自 1988 年种植人工芦苇以来,人工芦苇区面积呈持续增加趋势, 全湖芦苇蔓延, 经济利益的驱动无 可置疑, 但营养物质的过量排人对芦苇生长的影响也不容忽视, 如果不能有效控制其增长趋势, 芦苇区面积 将逐渐相连成片, 最终导致湿地功能的丧失.

综上所述, "引黄人海"工程的实施使得乌梁素海湿地环境得到一定改善,但仍然难以恢复昔日的功能 和景观, 而先污染后治理的途径也有悖于湖泊的自然发展规律, 因此, 只有人类与湿地环境和谐相处, 在环 境承载范围之内有效使用湿地资源, 才能保证湿地环境得以持续发展和永续利用. 


\section{6 参考文献}

[1] 赵学敏主编. 湿地: 人与自然和谐共存的家园一中国湿地保护. 北京: 中国林业出版社: 244 .

[2] 彭 敏,陈桂琛,周立华. 青海湖水位下降与湖区人为耗水关系的研究. 地理科学, 1994, 14 (2): $127-135$.

[3] Bennion H, Hilton J, Hughes M et al. The use of a GIS-based inventory to provide a national assessment of standing waters at risk from eutrophication in Great Britain. Science of the Total Environment, 2005,344 : $259-273$.

[4] OECD. Eutrophication of Waters, Monitoring, Assessment and Control. Paris: Organization for Economic Co-operation and Development, 1982.

[5] Sutcliffe D W, Jones J G. Eutrophication: Research and Application to Water Supply. Amble side Freshwater Biological Association, 1992: 217.

[6] Pieterse N M, Bleuten W, Jorgensen S E. Contribution of point sources and diffuse sources to nitrogen and phosphorus loads in lowland river tributaries. Journal of Hydrology, 2003, 271: 213 - 225.

[7] Carvalho L, Moss B. The current status of a sample of English Sites of Special Scientific Interest subject to eutrophication. Aquat Conserv Mar Freshw Ecosyst, 1995, 5: 191 - 204.

[8] Mainstone C P, Parr W. Phosphorus in rivers-ecology and management. Science of the Total Environment, $2002,282-283: 25-47$.

[9] Jordan C, Smith R V. Methods to predict the agricultural contribution to catchment nitrate loads : designation of nitrate vulnerable zones in Northern Ireland. Journal of Hydrology, 2005, 304: 316 - 329.

[10］王洪道,窦鸿身,颜京松等. 中国湖泊资源. 北京: 科学出版社, 1989, $142-168$

[11] Barko J W, Hardin D G, Matthews M S. Growth and morphology of submersed freshwater macrophytes in relation to light and temperature. Can J Bot, 1982, 60: $877-887$.

[12] Chambers P A, Kalff J. Depth distribution and biomass of submersed aquatic macrophyte communities in relation to secchi depth. Can J Fish Aquat Sci, 1985, 42: 701 - 709.

[13] Tracy E, Rea D J, Karapatakis K K et al. The relative effects of water depth, fetch and other physical factors on the development of macrophytes in a small southeastern US pond. Aquatic Botany, 1998, 61 : 289 299.

[14] 王伦平,陈亚新,曾国芳等. 内蒙古河套灌区灌溉排水与盐碱化防治. 北京: 水利电力出版社, 1993: 64 -76 .

[15] 王苏民,窦鸿身主编. 中国湖泊志. 北京: 科学出版社, 1998: 320 .

[16] 张奋清,王丽敏, 吴利斌等. 乌梁素海氮循环转化过程的初探. 内蒙古农业大学学报, 2004, 25(2): $31-34$.

[17] 叶雪梅. 中国主要湖泊营养氮沉降临界负荷的研究. 环境污染与防治, 2002, 24(1): $54-58$.

[18] 王丽敏, 尚士友, 吴利斌, 岳海军. 草型湖泊 (乌梁素海) 氮循环转化规律的研究. 环境科学动态, 2004 , (1) : $16-18$.

[19］赵 军. 乌梁素海芦苇资源的生产现状与展望. 内蒙古草业, 2001, (2)：47 - 48 .

[20] 段晓男,王效科, 欧阳志云等. 乌梁素海野生芦苇群落生物量及影响因子分析. 植物生态学报, 2004, 28 (2) :246 - 251.

[21] 杜健民, 李旭英. 乌梁素海富营养化及其防治研究. 内蒙古农业大学学报, 2003, 24(4): 6-12. 